\title{
CZECH WW2 CONCRETE FORTIFICATIONS: CORROSION PROCESSES AND REMEDIATION METHOD BASED ON CRYSTALLIZING COATING
}

\author{
JiŘí PAZDERKA $^{a, *}$, PAVEL REITERMAN $^{b}$ \\ ${ }^{a}$ Czech Technical University in Prague, Faculty of Civil Engineering, Department of Building Structures, \\ Thákurova 7, 16629 Praha 6, Czech Republic \\ ${ }^{b}$ Czech Technical University in Prague, Faculty of Civil Engineering, Experimental Centre, Thákurova 7, 16629 \\ Praha 6, Czech Republic \\ * corresponding author: jiri.pazderka@fsv.cvut.cz
}

\begin{abstract}
Concrete is a relatively new structural material, hence the remediation of concrete structures is very rare. There are a lot of concrete fortifications in the Czech Republic, which were built just before WW2. These bunkers formed a long defensive line along the Czechoslovak borders as a protection against Hitler's army. Today, after 80 years, many of the bunkers are listed as Czech national technical monuments with a strict protection of their historical authenticity. The article describes the technical survey and the possible conservation method of a selected concrete fortification, which exhibits a number of moisture related problems. The studied two-storey, heavily fortified bunker is situated close to the northern border of the Czech Republic, former Czechoslovakia. A detailed survey of the building includes the analysis of the interior environment parameters and laboratory testing of the used concrete. A long-term diagnosis identified the main problem, which lies in the inhomogeneity of the used concrete and the relating massive water ingress. However, the monitored bunker currently does not serve as a military structure and, therefore, a simple solution to improve the internal environment was suggested on the basis of the conducted measurements. With respect to the main causes of failures, the authors suggested a conservation method based on using a crystallizing coating. The suitability of the method was first verified under laboratory conditions and then also on the real bunker.
\end{abstract}

KEYWORDS: Fortification, WW2, concrete, corrosion, moisture, remediation, coating.

\section{INTRODUCTION}

The protection and conservation of historic monuments rank to significant engineering issues worldwide. Architecture and original building techniques form an integral part of the evolution of the human civilization and cultural heritage. There is a number of famous structures and monuments whose protection and remediation require a considerable care, which especially applies to relics of ancient civilizations [1 3 . The European region is known for a relatively large number of younger structures from the Gothic, Renaissance, Baroque, and other periods, and suitable procedures and techniques are formulated for their remediation. Their common feature is the application of original materials and technologies known at the time of their construction to maintain their historical authenticity. The $20^{\text {th }}$ century history is significantly marked by the massive utilization of concrete, which was widely used for a number of interesting structures and buildings. However, concrete is not perceived as a historical material by the public [4, hence the protection of concrete structures is very complicated.

There are a lot of small concrete fortifications in the Czech Republic built just before WW2 (on the territory of Czechoslovakia of that time). These buildings (bunkers) formed a long defensive line along the
Czechoslovak borders as a protection against Hitler's army, which was planning a massive attack. In the end, the defensive line was not used due to the $\mathrm{Mu}$ nich Agreement from September 1938 (Czechoslovakia was forced to surrender the border area to Germany). Thanks to this, the buildings remained intact by WW2. Today, after 80 years, some of these bunkers are listed as Czech national technical monuments, which ensures their protection.

The Czechoslovak WW2 defensive line consists mainly of light infantry bunkers known as "Model No. 37" (with indirect shooting positions) or their older version "Model No. 36" (with vulnerable direct loopholes). The problem of their underground protection against subsurface water penetration was solved by only one layer of the A/833 bitumen sheet (its designation conforms to the then used bitumen cardboard) with an additional double asphalt coating [5]. Unfortunately, in this inconvenient manner, the protection of underground structures was only provided in the case of extreme adverse hydro-physical conditions resulting from the rock environment; more often, the subsurface was only protected by using special cement based mortar (vertical walls) [5]. As a complement to the prevailing light infantry bunkers, heavy fortifications were also constructed in the areas where a major German offensive was assumed. That area 
was the region situated close to the northern border of the Czech Republic, approximately between the cities of Náchod and Ostrava (today, there is a border between the Czech Republic and Poland, but in 1938, there was a border between Czechoslovakia and Nazi Germany). Two-storey, heavily fortified bunkers complemented by a large artillery complex were built in this place. The article is focused on these two-storey, heavily fortified bunkers, which had massive ballistic protection, armoured observational towers and a lower floor (with a stock of ammunition) under the ground. The risk of subsurface water penetration into the structure was substantially higher than in the case of light non-cellar fortresses No. 37 and 36. However, a direct protection of underground structures was performed in the same unsatisfactory way, which means using the above mentioned cement based mortar on the walls and crushed rocks on the bottom [5]. In contrast with the light fortresses, heavy fortification elements were accompanied with a sophisticated system of indirect ways of protection against subsurface water formed by a drainage system along the building's perimeter. Next to that, the foundation base was widened and executed in a $2-5 \%$ gradient towards the building [5]. Quarried stone of fraction sizes $50-300 \mathrm{~mm}$ was stored above it to reduce the speed of dropped missiles. The present system of protection significantly contributed to the reduction of hydro-physical load [5].

The main problem of concrete structures is the presence of water, because most of the harmful degradation processes are closely related to that 6 [ 8 . Therefore, preventive approaches and structural solutions lead to the limitation of water ingress into the concrete structure [9].

The application of crystallizing materials is a very interesting option for the additional protection of reinforced concrete structures of the studied fortification buildings against the water ingress. The materials present in the form of coatings could be properly used to ensure the water impermeability of subsurface structures and ceilings as well. The final surface of all fortresses was equipped with cementitious mortar and a camouflage according to the surrounding terrain. The application of a crystalline coating will not affect the appearance of the buildings because it is based on Portland cement incorporated in the original mortar. This solution enables carrying out a new camouflage to keep the original look as well. The long-term effect of crystallizing coatings will have a significant impact on the reduction of water permeability and the increase in the durability of concrete structures.

Crystallizing materials are often used for the protection of underground parts of concrete buildings against ground moisture and subsurface water. There are many methods of the application of these materials to concrete structures: surface-applied coatings or spraying, repairing and sealing mortars and integral waterproofing admixtures. The crystallizing material consists of Portland cement, specially treated quartz sand and a compound of special chemicals. The composition of the special chemicals in the crystallizing material is thoroughly concealed by all producers. The crystallizing material's waterproofing effect in concrete is achieved by the reaction of the chemical components contained in the solution when combined within the concrete matrix [10 12. The special chemicals do not create any mysterious structure inside concrete, they only cause the hydration of not yet hydrated cement grains in concrete (therefore, the process is called "secondary hydration"). The special chemicals penetrate from the coating into the concrete structure using a concentration gradient in the open pore system filled with water (coating with active chemicals $=$ saturated solution, water in pores in concrete $=$ unsaturated solution). For this reason, a thorough moistening of the concrete before the coating application is necessary, but in the case of water leakage (which is a reason for the remediation), moistening is ensured by itself. Concrete with a crystallizing coating is completely effective against hydrostatic pressure as demonstrated by many successful laboratory tests presented in literature [13-25] and also by applications [26, 27]. The "depth effect" of crystallizing coatings was verified by a specific laboratory test based on using the electrical resistivity method [28. The crystalline coating is also beneficial for the remediation thanks to its properties in terms of the water vapour permeability - the crystallizing coating does not reduce the water vapour permeability of concrete 29 , due to this, there is no risk of condensation in the structure.

The present paper deals with a long-term diagnosis of the actual state of a concrete defensive fortification built in the 1930s and with a recommendation of a non-invasive procedure for its effective remediation. The interior parameters of the monitored bunker are also studied, as these originally military structures currently serve for different purposes. The recommended solution for the remediation of these structures is based on the previous research and practical experience.

\section{Site inspection AND USED METHODS}

\subsection{Description of Studied StruCture}

The authors of the article chose a well preserved, twostorey, heavily fortified bunker, R-S-74, near the town of Rokytnice v Orlických Horách, situated close to the northern border of the Czech Republic (former Czechoslovakia), for the building survey (Figure1 Figure 21. The bunker was not connected by underground tunnels to any other neighbouring buildings (detached building). The bunker was built in the highest class of resistance (of that time) - ceiling thickness: $2.6 \mathrm{~m}$, front wall: $2.75 \mathrm{~m}$, back wall: $1.25 \mathrm{~m}$. According to historical sources 30, the construction took place in 1937 - 1938, the concreting of bearing structures was carried out in December 1937. 


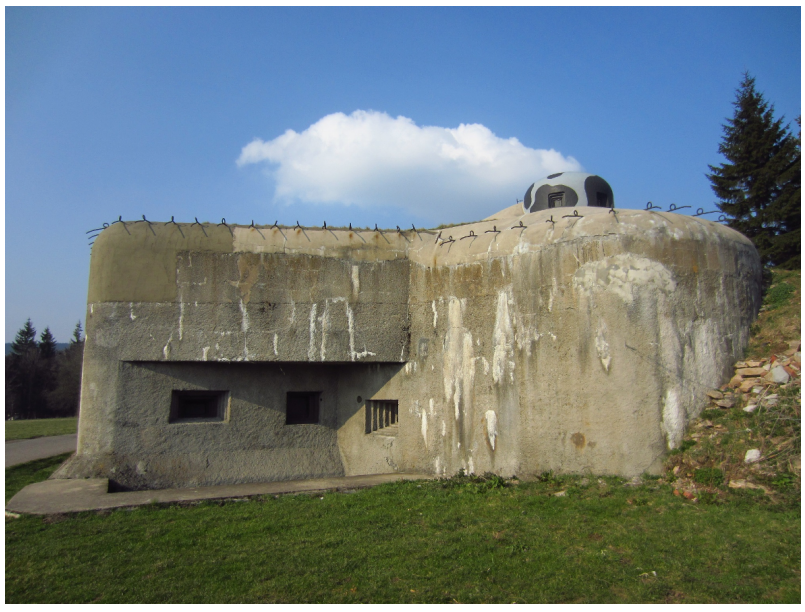

FIGURE 1. Contemporary appearance of the heavily fortified bunker R-S-74.

\begin{tabular}{ll}
\hline Hydrated mineral & $\begin{array}{l}\text { Solution concentration } \\
{[\mathrm{g} \mathrm{CaO} / \mathrm{l}]}\end{array}$ \\
\hline $2 \mathrm{CaO} \cdot \mathrm{SiO}_{2} \cdot n \mathrm{H}_{2} \mathrm{O}$ & Saturated solution \\
$3 \mathrm{CaO} \cdot 2 \mathrm{SiO}_{2} \cdot n \mathrm{H}_{2} \mathrm{O}$ & 1.10 \\
$\mathrm{CaO} \cdot \mathrm{SiO}_{2} \cdot n \mathrm{H}_{2} \mathrm{O}$ & 0.05 \\
$4 \mathrm{CaO} \cdot \mathrm{Al}_{2} \mathrm{O}_{3} \cdot 19 \mathrm{H}_{2} \mathrm{O}$ & 1.15 \\
$3 \mathrm{CaO} \cdot \mathrm{Al}_{2} \mathrm{O}_{3} \cdot 6 \mathrm{H}_{2} \mathrm{O}$ & $0.315-1.15$ \\
$2 \mathrm{CaO} \cdot \mathrm{Al}_{2} \mathrm{O}_{3} \cdot n \mathrm{H}_{2} \mathrm{O}$ & $0.17-0.315$ \\
$4 \mathrm{CaO} \cdot \mathrm{Fe}_{2} \mathrm{O} 3 \cdot n \mathrm{H}_{2} \mathrm{O}$ & 1.06 \\
$\mathrm{CaO} \cdot \mathrm{Al}_{2} \mathrm{O}_{3} \cdot n \mathrm{H}_{2} \mathrm{O}$ & $1.06-0.64$ \\
\hline
\end{tabular}

TABLE 1. Values of $\mathrm{Ca}(\mathrm{OH})_{2}$ concentrations necessary for the existence of hydrated clinker minerals.

\subsection{Moisture COnTEnt MONitoring}

The analysis of moisture contents in the monitored structure required a complex approach, hence the bunker was divided into smaller sections the distribution of which is shown in Figure 3 and Figure 4 All concrete interior walls were measured, except the walls with a steel plate facing where the measurement was impossible. Moisture was measured at three heights - the distances from the floor were $0.2 \mathrm{~m}, 1.2 \mathrm{~m}$ and $2.4 \mathrm{~m} ; 180$ points were measured in total. The moisture content measurement was conducted by using a non-destructive capacitive method preferably to limit invasions into the structure. However, the calibration by traditional gravimetric measurement (Eq. 1) was necessary for the required accuracy and reliability of this method. Additionally, samples for gravimetric measurement were extracted at different depths to assess the real moisture state of the concrete.

$$
w=\frac{m_{v}-m_{s}}{m_{s}} \cdot 100[\%]
$$

\subsection{SurfaCe EFFlorescence}

Structural concrete is always exposed to the action of a specific environment with which the interaction is going on. Its intensity primarily depends on single concrete components and the characteristics of the acting environment (concentration, temperature, humidity, etc.). The most frequent problem of both old and new concrete structures is the loss of the primary protection inherent in the natural alkalinity of the Portland cement based concrete. The alkalinity of concrete is ensured by the presence of $\mathrm{Ca}(\mathrm{OH})_{2}$, which is formed during the Portland cement hydration. This crucial component of the hardened cement paste with the highest solubility does not contribute to its mechanical properties; other hydrated silicates, aluminates and ferrites can, without doubt, only exist in specific solutions of $\mathrm{Ca}(\mathrm{OH})_{2}$, as shown in Table 1

The solution decrease of $\mathrm{Ca}(\mathrm{OH})_{2}$ in pore water leads to a gradual hydrolysis of hydrates and a consequent loss of mechanical properties. The significance of the presence of $\mathrm{OH}$-ions also consists in the passivation of steel integrated in the concrete mass and its natural protection against corrosion. The composition of the hardened cement paste is determined by the chemical properties of the used cement or, possibly, the application of active mineral additives, which are often used for the strengthening of the primary chemical resistance of concrete [31, 32. However, the kinetics of this type of concrete corrosion also depends on the mass of the flowing water. Water transport could be caused by both the increased permeability of the concrete and the existing cracks.

\subsection{Thermogravimetric ANALYSis OF EFFLORESCENCE}

Samples of efflorescence were collected during the site inspection. Subsequently, they were dried at $105^{\circ} \mathrm{C}$ and homogenized in the laboratory mill. Thermogravimetric analysis was performed on about $50 \mathrm{mg}$ of the resulting powder by monitoring the weight loss using a temperature rate of $10^{\circ} \mathrm{C} / \mathrm{min}$. The applied simultaneous DTA-TG apparatus (Schimadzu DTG-60H) uses an aerial condition in the measuring chamber. Exact boundaries were read from the derivative curve (DTG). Three samples were measured for each studied material.

\subsection{AIR HUMIDITY IN THE INTERIOR}

The infantry bunker R-S-74 is currently used as a recreational facility (for members of the Military History Club Prague, which is the owner of the building), so the issue of moisture also needs to be considered in terms of the indoor environment quality. With higher levels of air humidity, there is also an increased activity of microorganisms, which can release harmful spores into the air. Structures based on limestone carry out chemical reactions with water, which may cause higher concentrations of carbon dioxide in the air. Water firstly reacts with carbon dioxide and dissolves limestone into bicarbonates, Eq. 2, which can be dissolved in water.

$$
\mathrm{CaCO}_{3}+\mathrm{CO}_{2}+\mathrm{H}_{2} \mathrm{O} \longrightarrow \mathrm{Ca}\left(\mathrm{HCO}_{3}\right)_{2}
$$




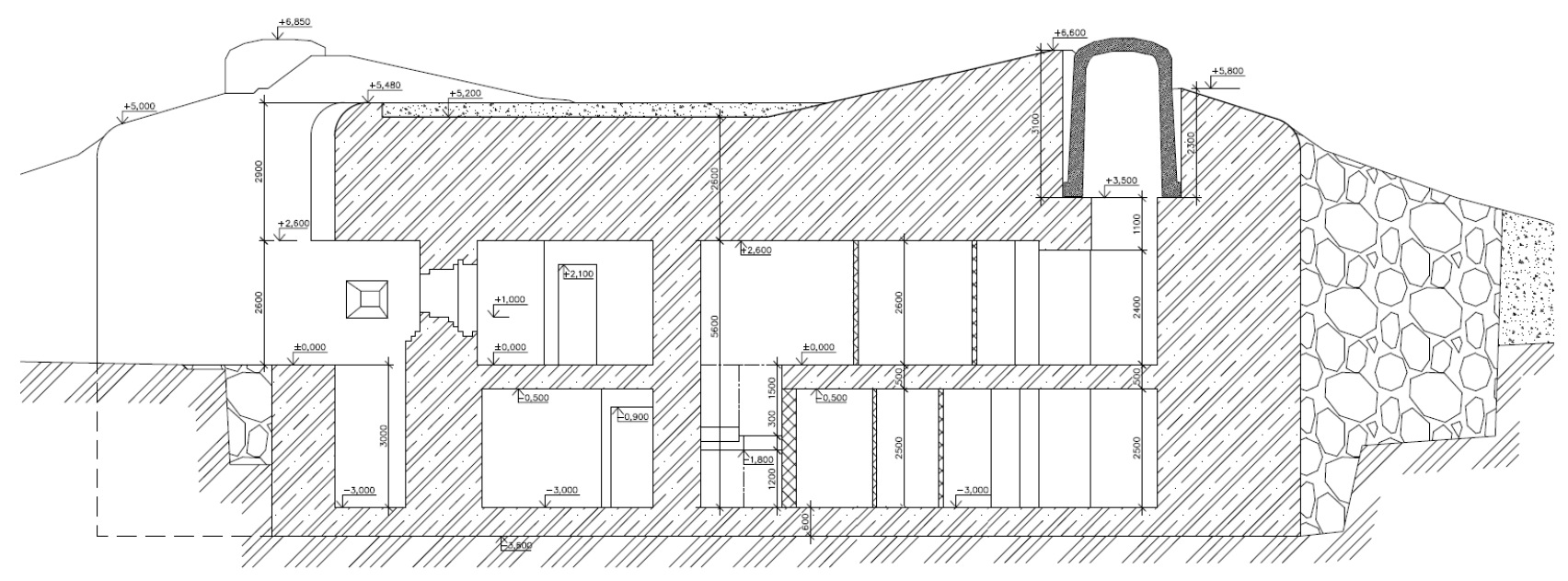

FiguRE 2. Vertical cross-section of the heavily fortified bunker R-S-74.

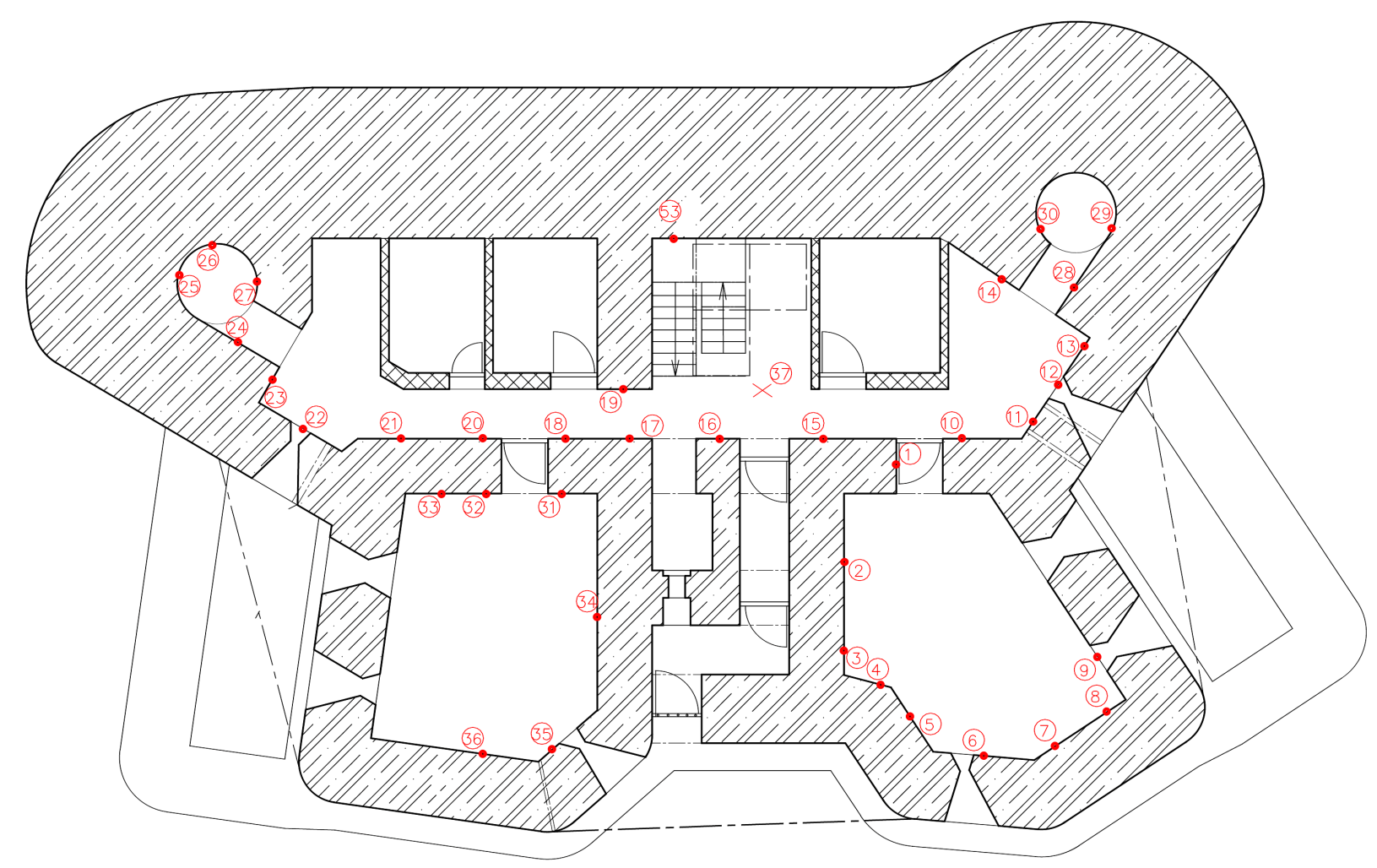

FIGURE 3. Internal layout of measurement points on the first (upper) floor. 


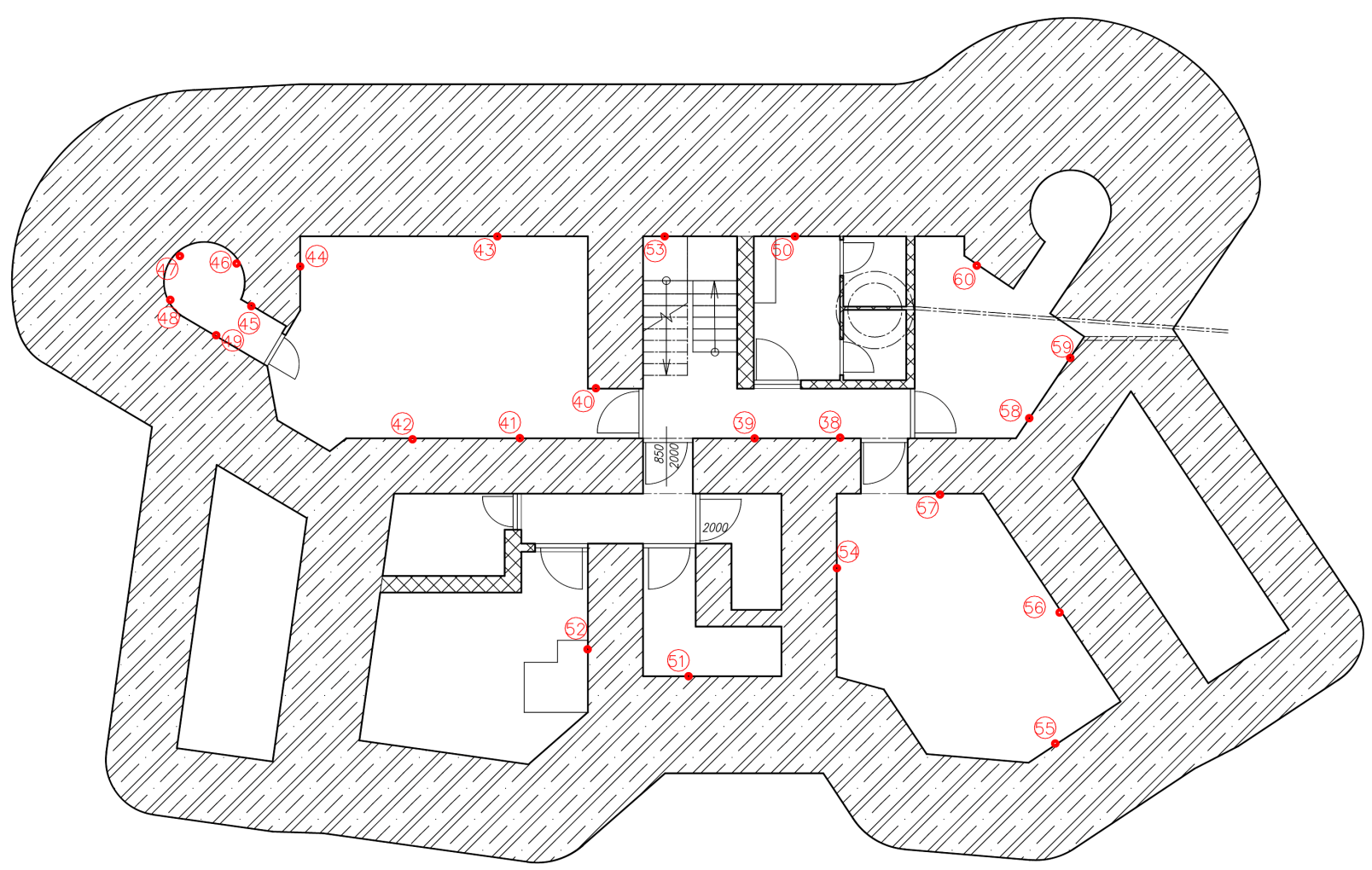

FiguRE 4. Internal layout of measurement points on the underground (lower) floor.

Thereafter, when this saturated water drips, $\mathrm{CO}_{2}$ is emitted into the air increasing its concentration in the air. Insoluble limestone is created by another chemical reaction and can be formed into sinter and stalactites, Eq. 3 .

$$
\mathrm{Ca}\left(\mathrm{HCO}_{3}\right)_{2} \longrightarrow \mathrm{CaCO}_{3}+\mathrm{CO}_{2}+\mathrm{H}_{2} \mathrm{O}
$$

The relative air humidity and carbon dioxide concentrations in the air inside the bunker were measured by an electronic hygrometer (Greisinger GFTH) in all rooms and also in the exterior.

\subsection{PeRMeABILITy PROPERTIES ASSESSMENT}

It has been found from historical sources 30 that the compressive strength of the used concrete after 28 days was just about $56 \mathrm{MPa}$ for the R-S-74 bunker (measured in 1938 by CTU in Prague). This shows a high skill of the builders in the 1930s because the bunker was built in December at an altitude of $750 \mathrm{~m}$ above sea level under very difficult climatic conditions. This concrete (56 MPa) should be practically waterproof, but, during the building survey, seepage inside the building was evident (confirmed by the current building owner).

The authors decided to conduct a laboratory testing of the concrete waterproofing according to EN 12390-8 [33] with a slight modification. There was a problem in obtaining samples from the R-S-74 bunker due to its preserved condition (the building is under national protection as a historical technical monument). Therefore, the authors decided to adopt a

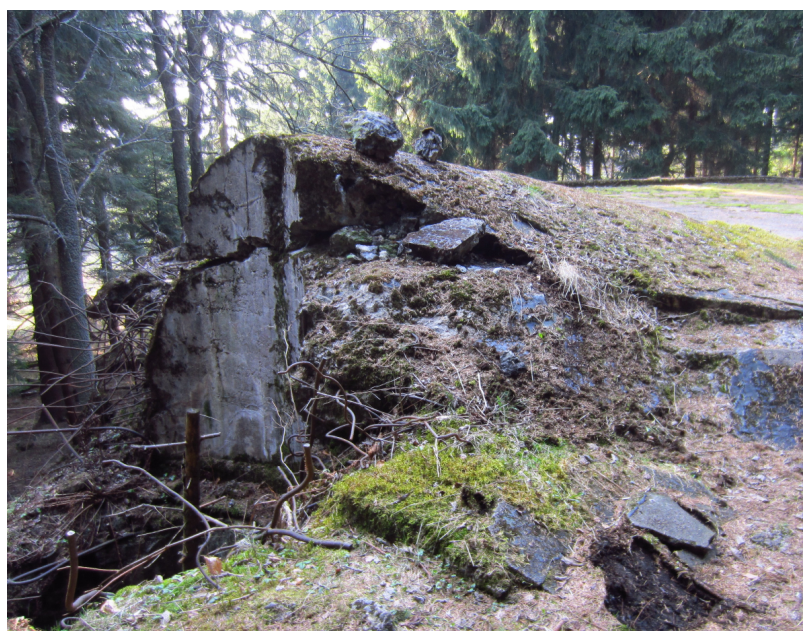

Figure 5. Sampling site - ruined structure of the nearby bunker R-S-73.

substitute solution: obtaining the samples from the nearby R-S-73 bunker, which had been heavily damaged shortly after WW2 by extracting raw materials. The obtained samples are part of the ruined structure, therefore, no damage was done to the historic bunker due to their extraction (Figure 5).

The laboratory testing of the samples was conducted according to EN 12390-8 33] and BS EN 206 34, with a slight modification consisting in modifying the sample dimensions. The samples were loaded by water pressure (0.5 MPa) for 72 hours (Figure 7 ). 


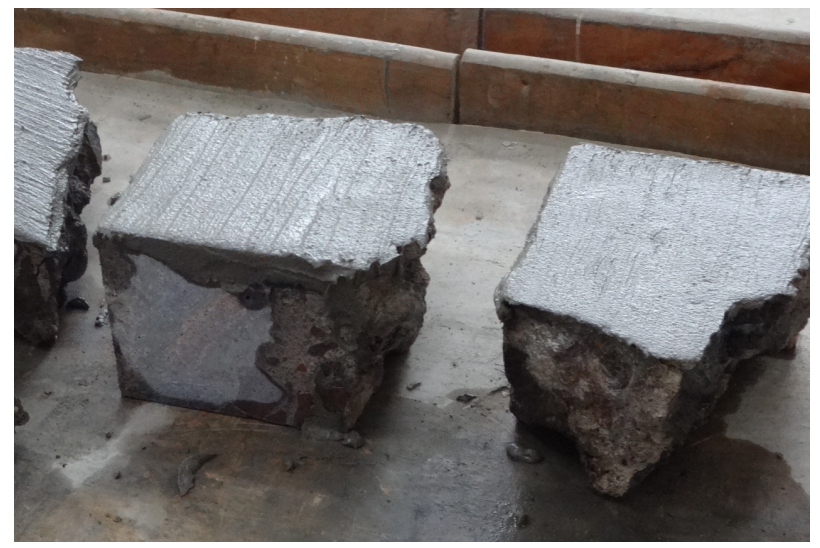

FiguRE 6. Samples with an applied crystallizing coating.

The maximum limit of water seepage on the fracture surface of each sample should by examined at the end of the test [33.

\subsection{APPLICATION OF CRYSTALLIZING MATERIALS}

Laboratory measurements were carried out on the basis of positive references documenting the sealing effect of crystallizing coatings to verify the possibilities of their successful application during the restoration of the fortification system from the 1930s. The Canadian crystallizing coating, Xypex Concentrate, was selected. The main aim of the performed programme was the assessment of the efficiency of the crystalline agent in improving the highly permeable part of concrete which is more than 80 years old, to reach its total water impermeability. Additional four pieces of concrete were extracted from the bunker No. R-S-73 for the test. They were partially fallen-off parts interconnected with the rest of the concrete structures by stickingout reinforcement rods. The dimensions and shapes of all samples were adjusted in the laboratory to be suitable for the water penetration test. Three samples were unilaterally treated with a crystallizing coating (Figure 6). The last sample was kept as a reference one, without any surface treatment. The samples were subsequently cured in a special box simulating real moisture conditions in the bunker.

The measurement of the water penetration depth (EN 12390-8 [6]) was carried out after four months of curing with respect to literature [35]. A longer time interval of the subsequent testing was chosen due to the high age of the treated concrete where a high rate of hydration was expected. The presence of any hydrating minerals is a necessary prerequisite for the efficiency and the start of the secondary hydration process. The dimensions of the used samples were not accurate according to EN 12390-8 [33] due to the above limitation during the sample extraction. The samples were subjected to a water pressure of $0.5 \mathrm{MPa}$, which corresponds to the hydrostatic pressure of a water column with $50 \mathrm{~m}$ in height (Figure 7).

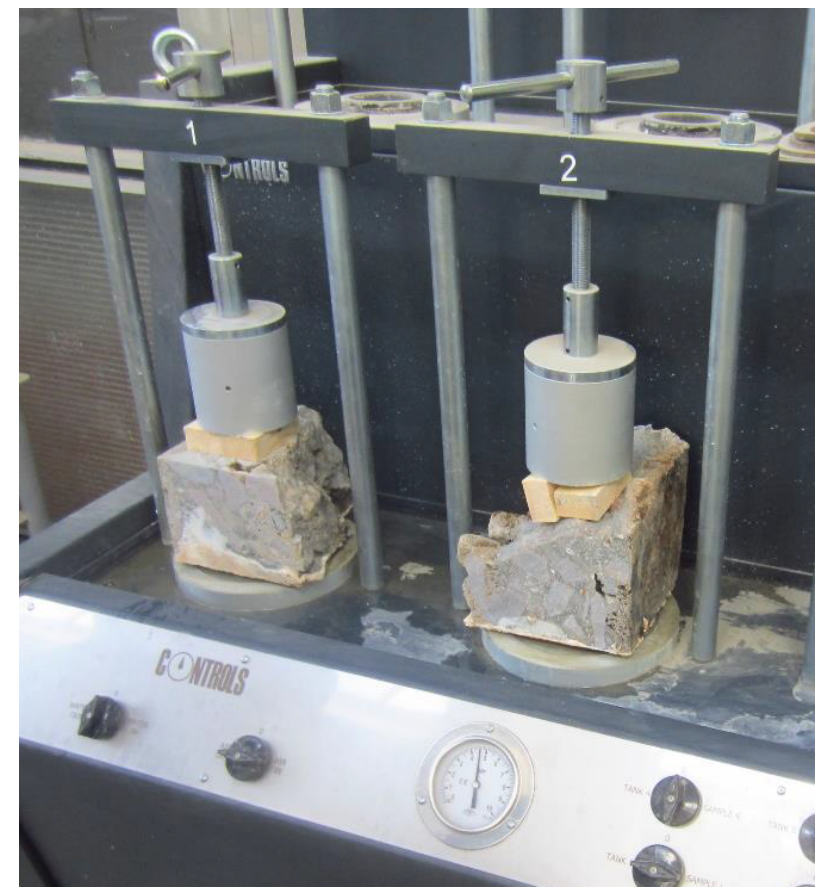

Figure 7. Samples with a crystallizing coating under the water penetration test (EN 12390-8).

\section{RESUlts AND DisCUSSION}

\subsection{Moisture CONTENT}

The obtained results indicated a slightly increased level of moisture in the structures in the whole bunker. The lowest value of moisture was $1.9 \%$, while the highest was $7.6 \%$ (in percentage by weight). All results are listed in the first floor and underground floor drawings. The results from spring and winter were compared, because, in winter, the bunker was covered by snow. The linear trend of the results displays that the measurement made in winter exhibits higher values than the measurement made in spring (Figure 8 , Figure 9. The moisture content in the structures is not too high on average, but water visibly leaks in many places. The causes were studied during the following inspection.

The results are shown in Table 2 The moisture values differed - from $2.8 \%$ to $9.2 \%$. Low moisture values were measured in the high quality part of concrete, while high moisture values were measured in the low quality parts of concrete (for more about the inhomogeneity of the concrete, see below). The results from the deeper samples showed minimal differences. The comparison of the capacity measurement and the measurement in a laboratory by the gravimetric method is listed in Table 3 Both results coincide with an accuracy of $\pm 30 \%$ in the worst case. When calculating the average moisture content value, the highest and the lowest values were discarded from the calculation. 
Moisture content in structures 1.NP

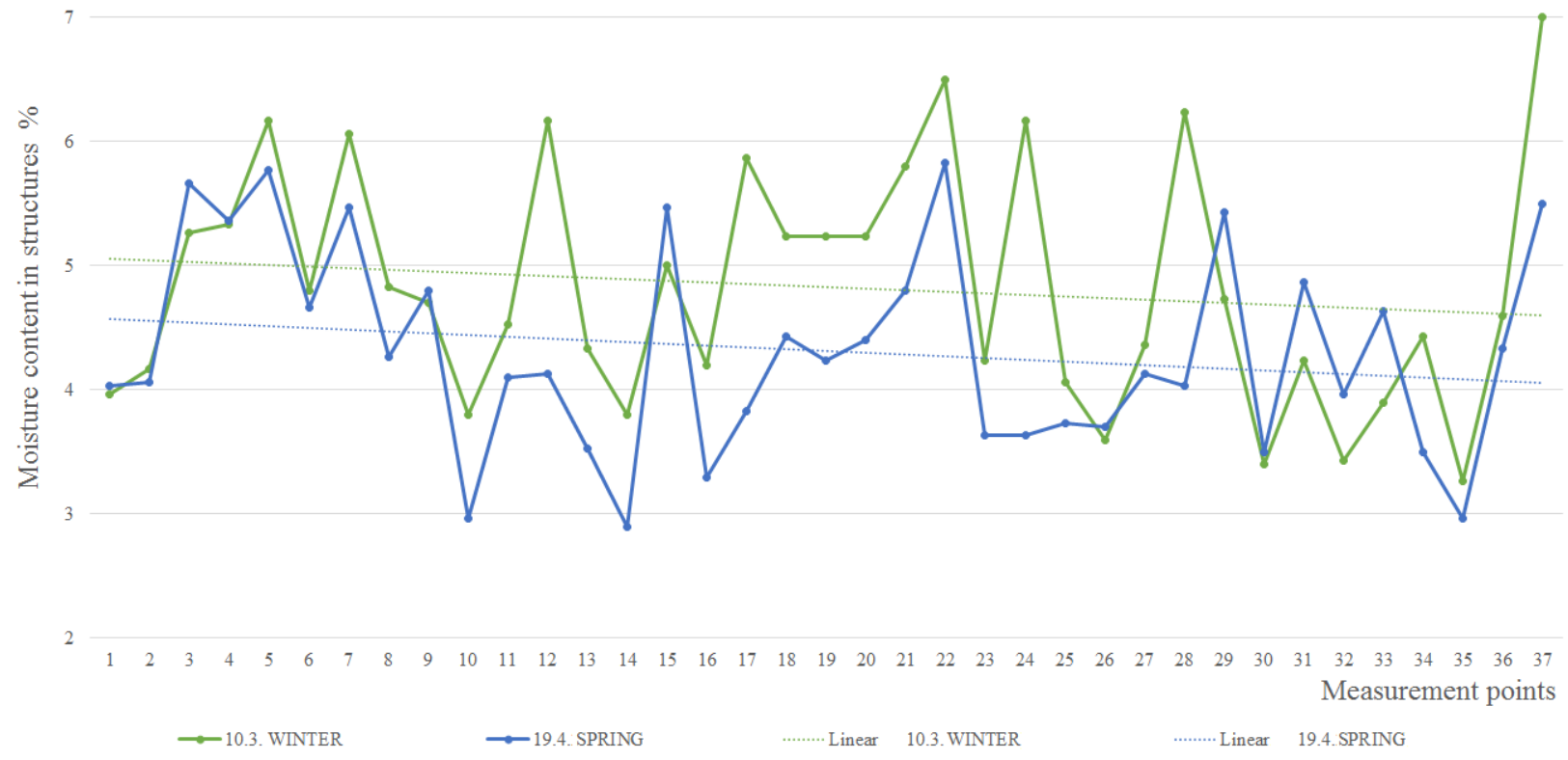

Figure 8. Comparison of moisture contents in structures measured in winter and spring - the first (upper) floor.

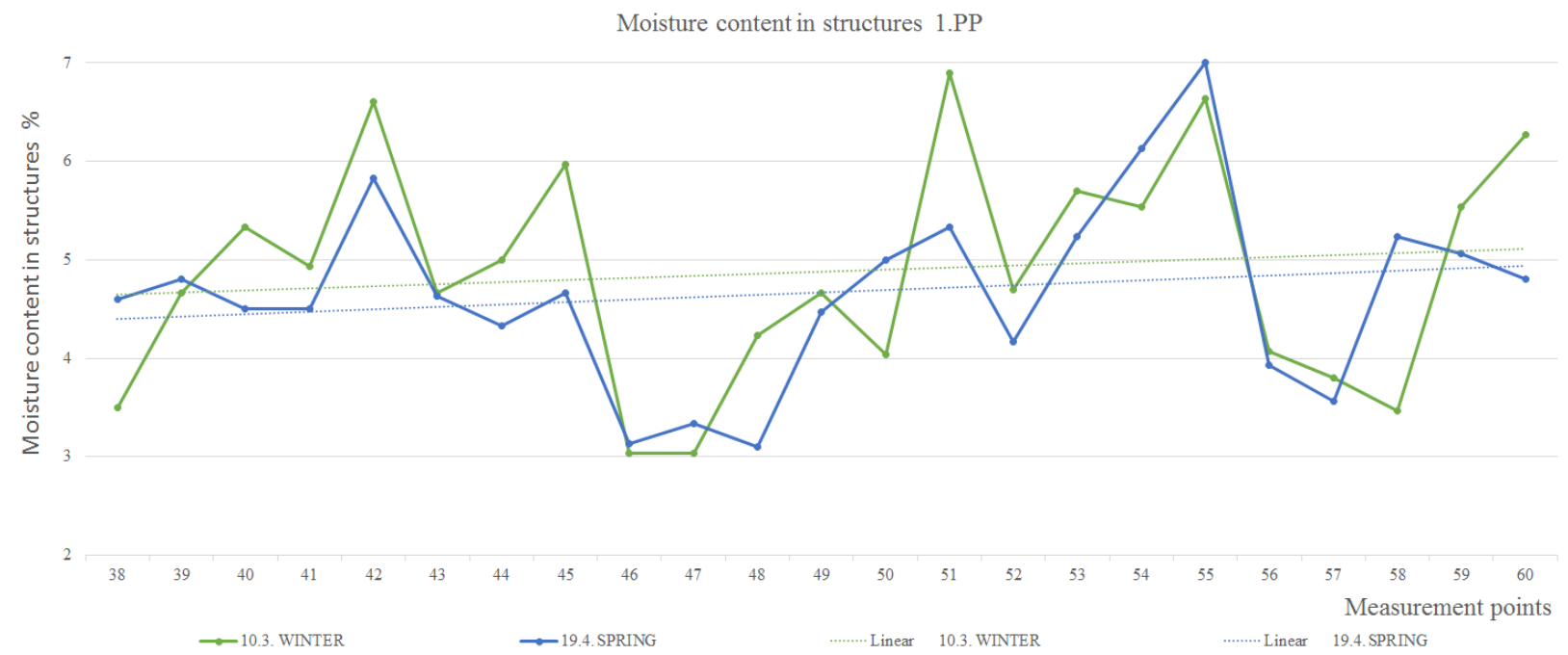

Figure 9. Comparison of moisture contents in structures measured in winter and spring - the underground (lower) floor.

\begin{tabular}{ccccc}
\hline \multicolumn{5}{c}{ Gravimetric method } \\
\hline \multirow{2}{*}{$\begin{array}{c}\text { Number } \\
\text { of sample }\end{array}$} & $\begin{array}{c}\text { Depth } \\
\text { of sample }\end{array}$ & $\begin{array}{c}\text { Mass } \\
\text { of moist sample }\end{array}$ & $\begin{array}{c}\text { Mass } \\
\text { of dry sample }\end{array}$ & Moisture \\
\cline { 3 - 5 } & & $m_{v}$ & $m_{s}$ & $w$ \\
& & {$[\mathrm{~g}]$} & 54.32 & {$[\%]$} \\
\hline 1 & Deep sample & 56.61 & 31.14 & 2.8 \\
2 & Surface sample & 32.01 & 53.96 & 9.2 \\
3 & Surface sample & 58.92 & 23.34 & 3.7 \\
4 & Surface sample & 24.21 & 33.74 & 4.3 \\
5 & Surface sample & 35.19 & 8.38 & 4.1 \\
6 & Deep sample & 8.72 & &
\end{tabular}

TABLE 2. Level of moisture in the structures - the gravimetric method. 


\begin{tabular}{ccccc}
\hline \multirow{2}{*}{$\begin{array}{c}\text { Type } \\
\text { of samples }\end{array}$} & \multicolumn{2}{c}{ Gravimetric method } & \multicolumn{2}{c}{ Capacitive moisture meter } \\
\cline { 2 - 5 } & $\begin{array}{c}\text { Depth } \\
\text { measurement }\end{array}$ & Moisture & $\begin{array}{c}\text { Depth } \\
\text { measurement }\end{array}$ & Moisture \\
\cline { 2 - 5 } & {$[\mathrm{mm}]$} & {$[\%]$} & {$[\mathrm{mm}]$} & {$[\%]$} \\
\hline Surface samples & $5-15$ & 5.0 & 10 & 6.4 \\
Deep samples & $15-30$ & 4.1 & 25 & 4.8 \\
\hline
\end{tabular}

TABLE 3. Level of moisture in the structures - comparison of the capacity measurement and the gravimetric method.

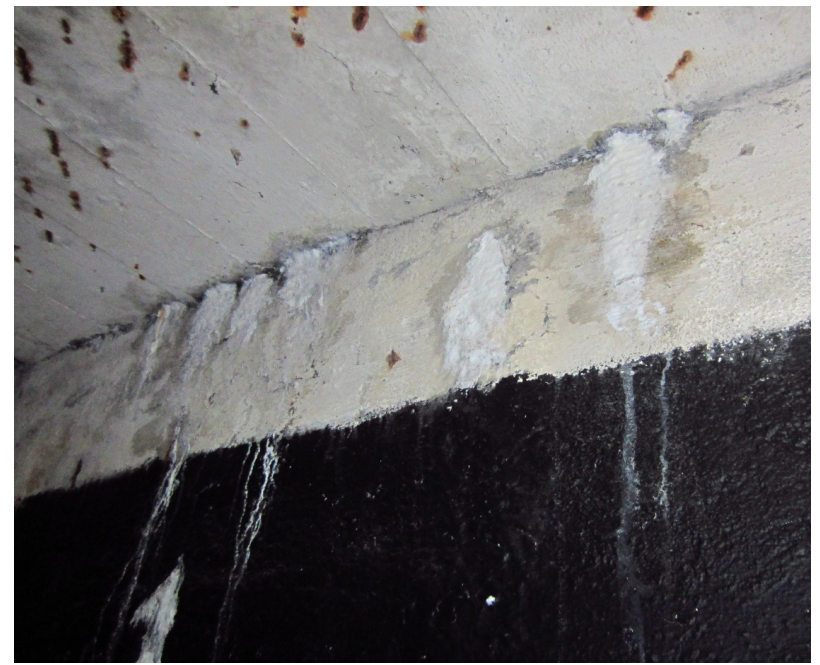

Figure 10. Surface efflorescence in the interior (bunker R-S-74).

\subsection{Surface EFflorescence}

A visual exhibition of the corrosion product is a typical efflorescence on the concrete surface originating from the leached $\mathrm{Ca}(\mathrm{OH})_{2}$ and its subsequent carbonation (Figure 10).

The results obtained after the thermogravimetric analysis and their comparison with the measurement on standard pure $\mathrm{CaCO}_{3}$ exhibited a high similarity. The TG curves were analysed for specific temperature intervals by monitoring the weight loss. The average weight loss for the efflorescence samples was $41.2 \%$ in a range of $615-918^{\circ} \mathrm{C}$, which presents the area of the calcite decomposition 36. The measured weight loss corresponds with the content of $93.85 \%$ of calcite in the studied efflorescence. The presence of calcite efflorescence caused by massive leaching of the binding components of the used concrete was confirmed.

\subsection{Air HUMidity IN THE INTERIOR}

The results are displayed in the graph in Figure 11. The chart is divided into individual floors and sorted by the air temperature value. The room temperature is influenced by the usage and placement of local heating (panel radiators), which were additionally installed in the 1980s. The inhabitants (members of the club) stay for a longer term only in the following rooms: club-room, bathroom, dormitory and a room called "střílna". These rooms should comply with the requirements for thermal comfort. The measured temperatures in these rooms, which were between $19.2-21.1^{\circ} \mathrm{C}$, fulfil the criteria for a long-term stay. The thermal performance model of the building was created from the values of the measured air humidity and air temperature (Figure 12, Figure 13, Figure 14). This was made by the "Area 2017" software (Svoboda Software Ltd.). The temperature and moisture values used were based on a real measurement performed in February.

From air humidity and temperature values, the temperature dew point can be calculated. The condensation of air humidity is possible, if the surface temperature is less or equal to the dew point temperature. From the data, which are shown in Table 4 it is almost certain that there will be no condensation in the measured heated room. But in the unheated rooms, the situation could be different - there is a higher risk of surface condensation so the heating of these rooms and forced ventilation is recommended.

The dormitory room, where the measurement was performed, serves as the place where most of the people in the bunker sleep. The room with this purpose should be adequately ventilated and the $\mathrm{CO}_{2}$ concentration should be less than $1500 \mathrm{ppm}$ according to EN ISO 16000-26:2012 37. The whole room is windowless with a one entrance, has a volume of $43.5 \mathrm{~m}^{3}$ and usually serves as an accommodation for 6 to 10 people. Unfortunately, there was no possibility to measure the above data for a longer time and examine the $\mathrm{CO}_{2}$ variability over day and night. The measurement was performed in February from 11:30 until 13:40 with a frequency of once per 10 minutes. The highest measured value reached $2703 \mathrm{ppm}$, which is by about $80 \%$ more than the value acceptable by EN ISO 1600026:2012 [37]. During this measurement, there were no more than two people in the room. In the case of six or more people in the room, a higher concentration of $\mathrm{CO}_{2}$ can be achieved - it could then have a harmful effect on their health.

Sometime after the start of the measurement, two people stayed in the room for a limited time. These minor changes in the room occupancy are easy to spot in the graph in Figure 15. The highest values were measured when people were present in the room. Due to the probe placement on the other side of the room, a devaluation by a direct exhalation on the $\mathrm{CO}_{2}$ probe was not possible. 
Relative air humidity and air temperature

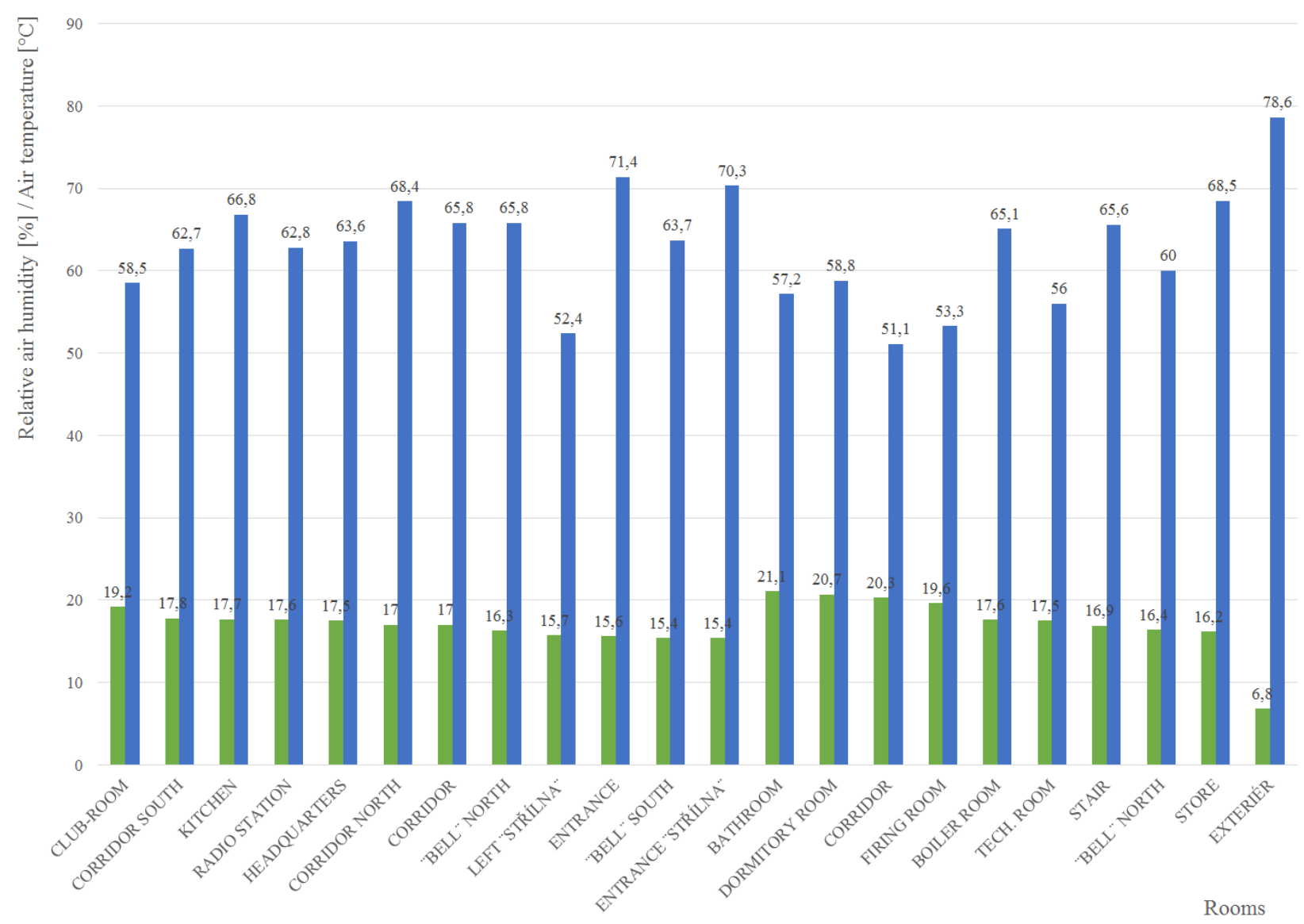

FiguRE 11. Graph of relative air humidity and air temperature measured in spring.

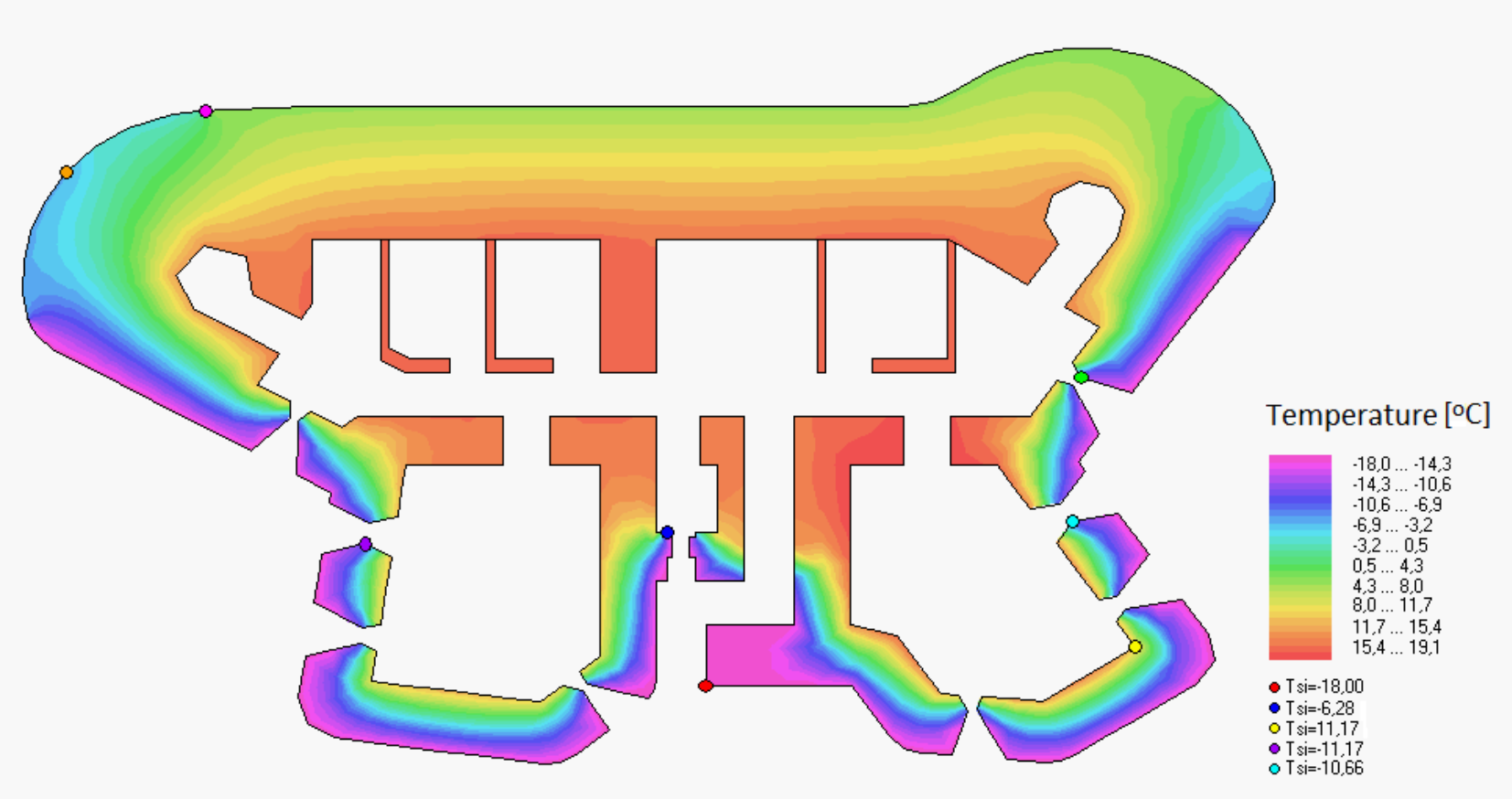

FiguRE 12. 2D thermal performance model of the first floor (Area 2017). 


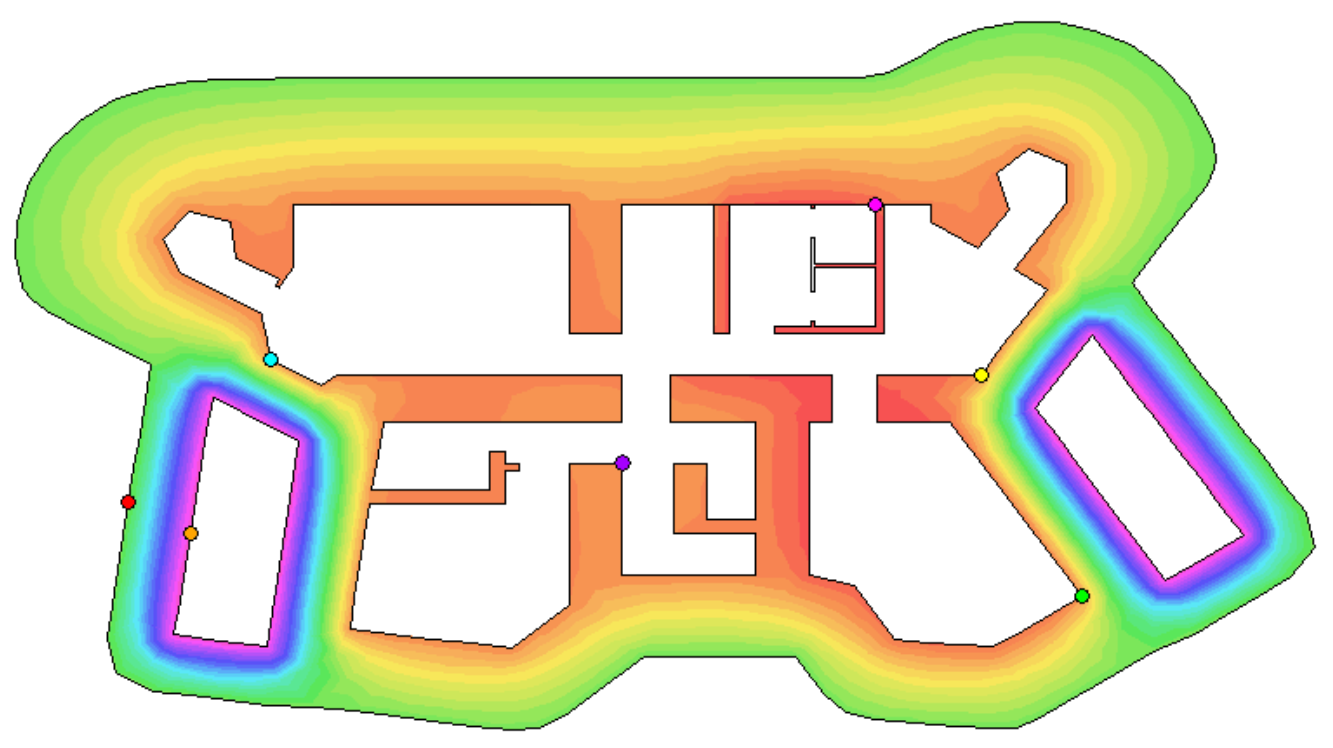

Temperature $\left[{ }^{\circ} \mathrm{C}\right]$

FiguRE 13. 2D thermal performance model of the underground floor (Area 2017).

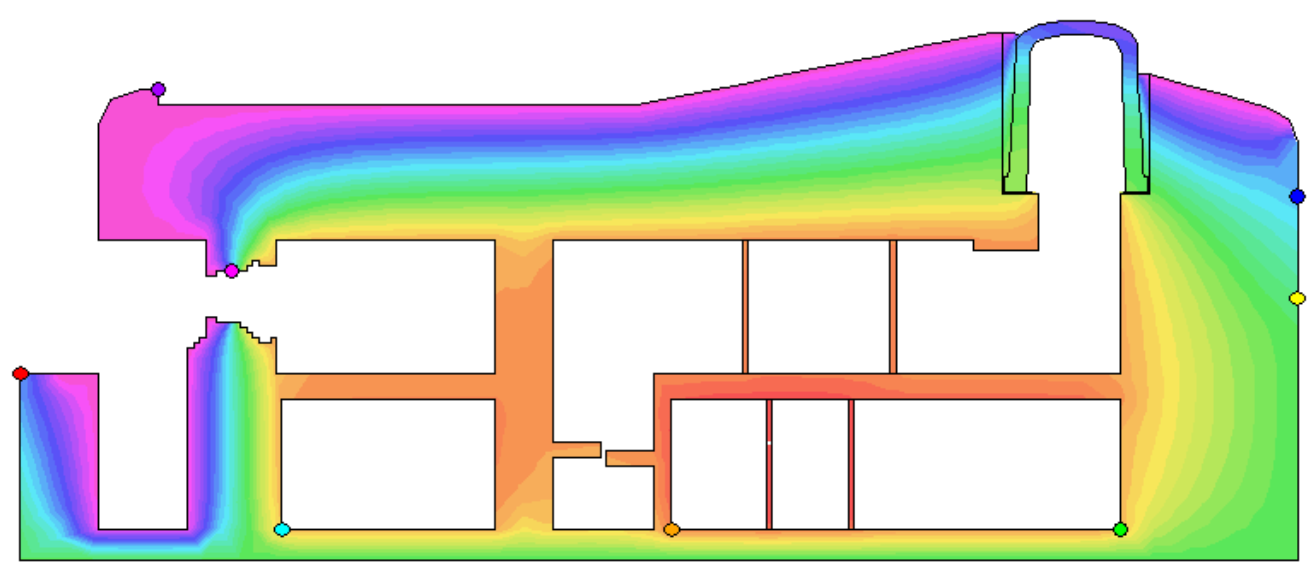

Temperature $\left[{ }^{\circ} \mathrm{C}\right]$

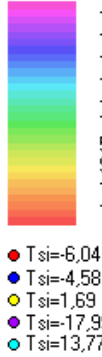

FIGURE 14. 2D thermal performance model of the cross-section (Area 2017).

The air humidity measured in the rooms equipped with the heating was only slightly higher compared to the standard interior requirements. It was confirmed that the source of the moisture in the most damaged rooms was not condensed water on the walls. With a high probability, water seeps into the bunker from the exterior. The interior air quality in terms of carbon dioxide concentrations easily exceeds limits [37] and it is highly recommended to use a forced ventilation.

\subsection{Permeability properties assessment}

Based on the studies of fracture surfaces, it is evident that the concrete used for the construction of the historic bunker consists of high-quality (waterproof) and low-quality (permeable) parts. The observed inhomogeneity could be caused by poor workmanship insufficient concrete compaction, a bad ratio of mixed components, or due to severe weather conditions during the construction - low temperatures, heavy snow, strong wind. However, the frequent inhomogeneity in the concrete resulted in its high permeability, which was well manifested during the testing. The extracted samples exhibited massive seepage during the water penetration test (Figure 16). The inhomogeneity of the studied concrete is well visible in Figure 17.

In this case, water had penetrated through each sample during the test (before the end of the time limit). The concrete samples were, therefore, permeable. A subsequent study of the fracture surface of the sample shows that the sample contains different parts with a different permeability (Figure 17).

\subsection{ApPLICATION OF CRYSTALIZING MATERIALS}

The maximal obtained depth of the water penetration reached values of up to $2 \mathrm{~mm}$, which highly exceeds common requirements for all exposure classes defined in EN 206 [34. The effectiveness of the remediation 


\begin{tabular}{|c|c|c|c|c|c|c|}
\hline $\begin{array}{c}\text { Time } \\
\text { of } \\
\text { measurement }\end{array}$ & $\begin{array}{c}\text { Air } \\
\text { temperature }\end{array}$ & $\begin{array}{c}\text { Relative } \\
\text { air } \\
\text { humidity }\end{array}$ & $\begin{array}{c}\text { Temperature } \\
\text { dew } \\
\text { point }\end{array}$ & \multirow{2}{*}{ 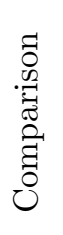 } & $\begin{array}{c}\text { Surface } \\
\text { temperature }\end{array}$ & \multirow{2}{*}{ 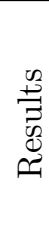 } \\
\hline [h:m:s] & $\begin{array}{l}\mathrm{D} 2 \\
{\left[{ }^{\circ} \mathrm{C}\right]}\end{array}$ & $\begin{array}{l}\mathrm{D} 2 \\
{[\%]}\end{array}$ & {$\left[{ }^{\circ} \mathrm{C}\right]$} & & $\begin{array}{l}\mathrm{D} 1 \\
{\left[{ }^{\circ} \mathrm{C}\right]}\end{array}$ & \\
\hline 11:30:00 & 18.0 & 55.6 & 8.99 & \multirow{14}{*}{$<$} & 16.8 & \multirow{14}{*}{ 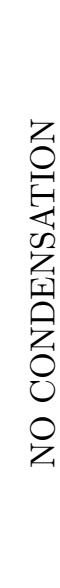 } \\
\hline 11:40:00 & 18.9 & 56.1 & 9.96 & & 16.6 & \\
\hline 11:50:00 & 19.5 & 54.8 & 10.17 & & 16.0 & \\
\hline 12:00:00 & 20.2 & 53.3 & 10.41 & & 15.6 & \\
\hline 12:10:00 & 20.4 & 51.0 & 9.93 & & 15.4 & \\
\hline 12:20:00 & 20.3 & 51.8 & 10.07 & & 15.2 & \\
\hline 12:30:00 & 20.7 & 42.8 & 7.61 & & 15.2 & \\
\hline 12:40:00 & 20.7 & 38.8 & 6.18 & & 15.1 & \\
\hline 12:50:00 & 20.9 & 41.2 & 7.24 & & 15.1 & \\
\hline 13:00:00 & 20.8 & 40.2 & 6.79 & & 15.1 & \\
\hline 13:10:00 & 20.8 & 41.8 & 7.36 & & 15.0 & \\
\hline 13:20:00 & 21.0 & 43.6 & 8.16 & & 15.0 & \\
\hline 13:30:00 & 21.2 & 46.3 & 9.23 & & 15.0 & \\
\hline 13:40:00 & 21.4 & 44.3 & 8.76 & & 15.1 & \\
\hline
\end{tabular}

TABLE 4. Condensation possibility of air humidity, measured in spring.

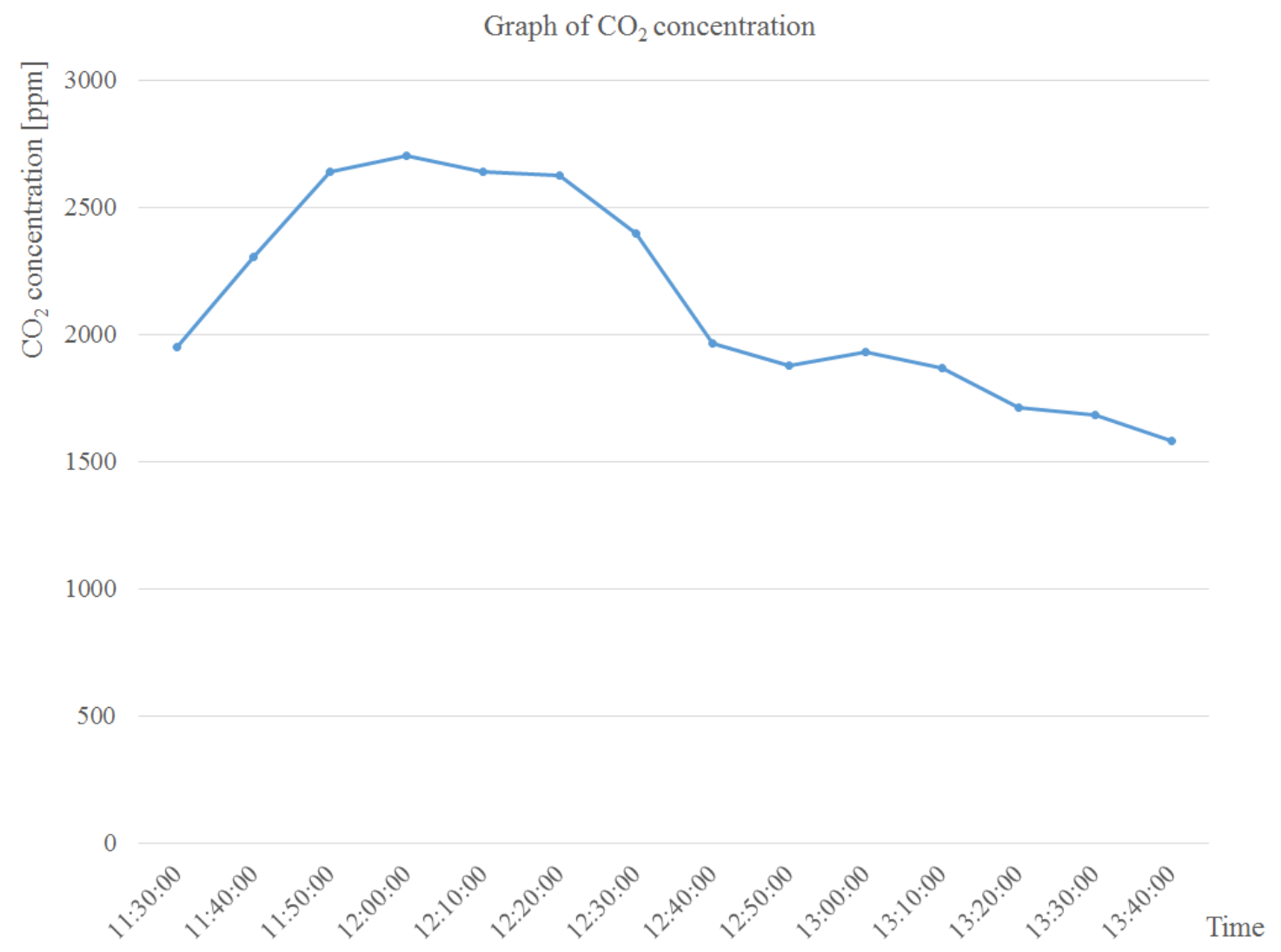

FIgURE 15. Measured values of carbon dioxide concentrations in the dormitory room. 


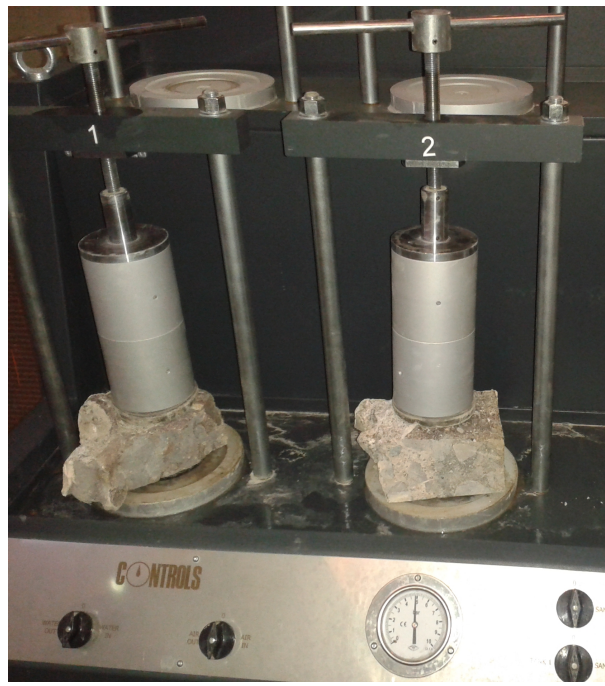

Figure 16. Sample from the bunker R-S-73 under the water penetration test (EN 12390-8).

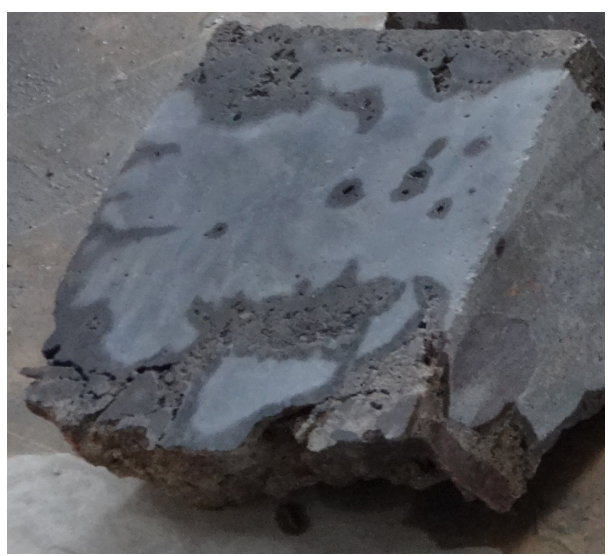

FiguRE 17. Heterogeneous structure on the fracture surface of the sample.

procedure was verified. The results manifest the sealing effect of the used surface crystallizing treatment (Xypex Concentrate), which had been confirmed in other studies [13 18]. Highly permeable parts of the historical army structure were positively influenced by the gradual secondary crystallization so that the entire mass of concrete could be considered as impermeable. Now, the application to real bunkers will follow.

\section{Conclusions}

The performed program was focused on a systematic analysis of the actual state of a historical monument made of concrete. The monitored structure exhibited a number of water-related failures. The environment parameters inside the bunker were investigated as well. Obtained findings are summarized below:

- A massive ingress of water is caused by the inhomogeneity of the used concrete and failures of the waterproof envelope. The water transport led to the significant leaching of portlandite resulting in the surface calcite efflorescence.
- The presence of condensed water is caused by the different regime of the current usage, which significantly differs from the original design. That could be properly solved by the ventilation installation. The internal environment has no impact on the concrete deterioration.

- Laboratory testing exhibited a suitable efficiency of the crystallizing admixtures in terms of the water permeability test. These results were confirmed by operational tests.

- The application of crystalizing admixtures performs a perspective technique, which allows a preservation of the original character of the concrete fortifications.

\section{ACKNOWLEDGEMENTS}

This work was supported by the Czech Ministry of Culture under grant no. DG18P02OVV063 - Development of a Progressive Rehabilitation Methodology for the Restoration and Conservation of Military Fortress Structures from the 1930s.

\section{REFERENCES}

[1] A. Taliercio, L. Binda. The Basilica of San Vitale in Ravenna: Investigation on the current structural faults and their mid-term evolution. Journal of Cultural Heritage 8:99-118, 2007. DOI:10.1016/j.culher.2006.09.005

[2] I. Bany Yaseen, H. Al-Amoush, M. Al Farajat, S. Mayyas, Abdulraouf. Petrography and mineralogy of Roman mortars from buildings of the ancient city of Jerash, Jordan. Construction and Building Materials 38:465-471, 2013. DOI:10.1016/j.conbuildmat.2012.08.022.

[3] A. Al-Sibahy, R. Edwards. Characterization of the clay masonry units and construction technique at the ancient city of Nippur. Engineering Structures 147:517-529, 2017. DOI:10.1016/j.engstruct.2017.06.017

[4] H. A. Heinemann, R. P. J. van Hees, T. G. Nijland. Concrete: Too young for conservation? In Proceedings of 6th International conference on Structural analysis of historic constructions: preserving safety and significance, vol. 1, pp. 151-159. 2008.

[5] J. Pazderka, M. Purkrtová, P. Reiterman. Moisture-related problems of historic concrete structure. Materials Science Forum 865:219-223, 2016. DOI:10.4028/www.scientific.net/MSF.865.219.

[6] R. P. J. van Hees, B. Lubelli, A. Hacquebord. New test methods to verify the performance of chemical injections to deal with rising damp. Journal of Cultural Heritage 31:S52-S59, 2018. DOI:10.1016/j.culher.2018.03.024.

[7] P. A. Claisse. Transport Properties of Concrete: Measurements and Applications. Woodhead Publishing Series in Civil and Structural Engineering, 2014. DOI:10.1533/9781782423195

[8] J. A. Larbi, A. L. A. Fraay, J. M. J. M. Bijen. The chemistry of the pore fluid of silica fume-blended cement systems. Cement and Concrete Research 20(4):506-516, 1990. DOI:10.1016/0008-8846(90)90095-F. 
[9] M. Sánchez Moreno, P. Faria, L. Ferrara, et al. External treatments for the preventive repair of existing constructions: A review. Construction and Building Materials 193:435-452, 2018. DOI:10.1016/j.conbuildmat.2018.10.173

[10] C. Edvardsen. Water penetrability and autogenous healing of separation cracks in concrete. Betonwerk und Fertigteil-Technik 62(11):77-85, 1996.

[11] V. Rahhal, V. Bonavetti, A. Delgado, et al. Scheme of the Portland cement hydration with crystalline mineral admixtures and other aspects. Silicates Industriels 74:347-352, 2009.

[12] T. Scancella, J. Robert. Use of Xypex admixture to concrete as an inhibitor to reinforcement steel corrosion. In Proceedings of the Materials Engineering Conference, vol. 2, pp. 1276-1280. 1996.

[13] M. Al-Kheetan, M. Rahman, D. A. Chamberlain. Influence of early water exposure on modified cementitious coating. Construction and Building Materials 141:64-71, 2017. DOI:10.1016/j.conbuildmat.2017.02.159

[14] M. Rahman, D. A. Chamberlain. Application of crystallising hydrophobic mineral and curing agent to fresh concrete. Construction and Building Materials 127:945-949, 2016. DOI:10.1016/j.conbuildmat.2016.08.150

[15] M. Rahman, D. A. Chamberlain. Performance of crystalline hydrophobic in wet concrete protection. Journal of Materials in Civil Engineering 29:04017008, 2017. DOI:10.1061/(ASCE)MT.1943-5533.0001779.

[16] M. Al-Kheetan, M. Rahman, D. A. Chamberlain. A novel approach of introducing crystalline protection material and curing agent in fresh concrete for enhancing hydrophobicity. Construction and Building Materials 160:644-652, 2018. DOI:10.1016/j.conbuildmat.2017.11.108

[17] M. Al-Kheetan, M. Rahman, D. A. Chamberlain. Remediation and protection of masonry structures with crystallising moisture blocking treatment. International Journal of Building Pathology and Adaptation 36:77-92, 2018. DOI:10.1108/IJBPA-02-2017-0011

[18] M. Al-Kheetan, M. Rahman, D. A. Chamberlain. Development of hydrophobic concrete by adding dual-crystalline admixture at mixing stage. Structural Concrete 19:1504-1511, 2018. DOI:10.1002/suco.201700254

[19] L. Baltazar, J. Santana, B. Lopes, et al. Surface skin protection of concrete with silicate-based impregnations: Influence of the substrate roughness and moisture. Construction and Building Materials 70:191-200, 2014. DOI:10.1016/j.conbuildmat.2014.07.071.

[20] M. Ru Zhou, G. Jing Cui, L. Jian Gao, H. Xia Qiao. Study on experiment of concrete compounding XYPEX and steel fiber. Applied Mechanics and Materials 105-107:1755-1759, 2011. DOI:10.4028/www.scientific.net/AMM.105-107.1755.

[21] V. García-Vera, A. Tenza-Abril, J. Saval, M. Lanzón. Influence of crystalline admixtures on the short-term behaviour of mortars exposed to sulphuric acid. Materials 12:82, 2018. DOI:10.3390/ma12010082
[22] J. Kotátková, K. Kolářr. Long-term sorption properties of modified concrete surface layer. vol. 1978, p. 250006. 2018. DOI:10.1063/1.5043881.

[23] P. Reiterman, V. Bäumelt. Long-term sorption properties of mortars modified by crystallizing admixture. Advanced Materials Research 1054:71-74, 2014. DOI:10.4028/www.scientific.net/AMR.1054.71

[24] S. Bohus, R. Drochytka. Cement based material with crystal-growth ability under long term aggressive medium impact. Applied Mechanics and Materials 166-169:1773-1778, 2012. DOI:10.4028/www.scientific.net/AMM.166-169.1773.

[25] P. Reiterman, J. Pazderka. Crystalline coating and its influence on the water transport in concrete. Advances in Civil Engineering 2016:1-8, 2016. DOI:10.1155/2016/2513514

[26] J. Pazderka, E. Hájková, M. Jiranek. Underground air duct to control rising moisture in historic buildings: Improved design and its drying efficiency. Acta Polytechnica 57:331, 2017. DOI:10.14311/AP.2017.57.0331.

[27] V. Dao, P. Dux, P. H. Morris, A. H. Carse. Performance of permeability-reducing admixtures in marine concrete structures. ACI Materials Journal 107:291-296, 2010.

[28] J. Pazderka, P. Reiterman. Depth impact of crystalline coating measured by electrical resistivity method. Concrete 48:20-21, 2014.

[29] J. Pazderka, E. Hájková. Crystalline admixtures and their effect on selected properties of concrete. Acta Polytechnica 56:306-311, 2016. DOI:10.14311/AP.2016.56.0306

[30] F. Stehlík, V. Kupka. Pěchotní srub Na Holém. Fortprint, Dvůr Králové nad Labem, 1994.

[31] V. Limbachiya, E. Ganjian, P. Claisse. Strength, durability and leaching properties of concrete paving blocks incorporating GGBS and SF. Construction and Building Materials 113:273-279, 2016. DOI:10.1016/j.conbuildmat.2016.02.152.

[32] M. Vyšvařil, P. Bayer, M. Rovnaníková. Microstructural changes of fine-grained concrete exposed to a sulfate attack. Materiali in tehnologije 49:883-888, 2015. DOI:10.17222/mit.2014.138.

[33] EN 12390 - Testing hardened concrete, Part 8 Depth of penetration of water under pressure. Standard, European Commitee for Standardization, Brussels, 2009.

[34] EN 206 - Concrete - Specification, performance, production and conformity. Standard, British Standards Institution, London, 2014.

[35] R. Barnes. Permeability Testing of Site Concrete. The Concrete Society, Camberley, 2008.

[36] G. A. Novak, A. A. Colville. Efflorescent mineral assemblages associated with cracked and degraded residential concrete foundations in Southern California. Cement and Concrete Research 19(1):1-6, 1989. DOI:10.1016/0008-8846(89)90059-8

[37] EN ISO 16000-26 - Indoor air. Sampling strategy for carbon dioxide $\left(\mathrm{CO}_{2}\right)$. Standard, International Organization for Standardization, Geneva, 2012. 